\title{
No Correlation Between Anemia in Third Trimester Pregnant Women and Preeclampsia/Eclampsia in Dr. Seotomo Hospital Surabaya
}

\author{
Lila Amila ${ }^{1}$, Ni Wajan Tirthaningsih ${ }^{1}$, Aditiawarman ${ }^{1}$ \\ Airlangga University, Mayjen Prof Dr. Moestopo number 47, Surabaya \\ 60132. Indonesia \\ email: lila.amila-2018@fk.unair.ac.id
}

\begin{abstract}
Based on the latest survey data, Indonesia's Maternal Mortality Rate (MMR) is 305/100,000 live births. One of the the most common cause of Maternal Mortality Rate is Preeclampsia. Globally, preeclampsia is still a problem associated with MMR. $10 \%$ of pregnant women worldwide experience preeclampsia, and it is the cause of 76,000 maternal deaths and 500,000 infant deaths each year. According to World Health Organization (WHO), it is reported that the global prevalence of eclampsia is $0.3 \%$, causes of maternal death ranged from 1.5 percent to 25 percent. In addition to other vascular disorder, anemia considered high with prevalence of $49.8 \%$ in Indonesia. There have not been many significant studies on the effect of anemia with the incidence of preeclampsia and eclampsia. This study aims to explore the correlation between risk factor of anemia and the incidence of preeclampsia and eclampsia in Dr. Soetomo Hospital Surabaya, Indonesia. This research was carried out with cross-sectional studies with total samples of 141 pregnant woman in Dr. Soetomo Hospital Surabaya, Indonesia. Age characteristics taken are 18-35 years old. Primigravida $(33.33 \%)$, multigravida $(66.70 \%)$. Hb $<11 \mathrm{~g} / \mathrm{dL}$ $(40.40 \%)$, > $11 \mathrm{~g} / \mathrm{dL}(59.60 \%)$. Patients with anemia and preeclampsia/eclampsia (30.60\%), without preeclampsia/eclampsia $(69.40 \%)$. Patients without anemia with preeclampsia $(52.20 \%)$, without preeclampsia/eclampsia $(47.80 \%)$. The results of Chi Square analysis found no significant correlation between anemia with the prevalence of preeclampsia $(\mathrm{p}=0.062)$ at Dr. Soetomo Hospital, Surabaya, Indonesia.
\end{abstract}

Keyword: Preeclampsia, Eclampsia, Anemia, Characteristics, Risk Factors.

\section{Introduction}

Maternal mortality is still a problem in many parts of the world, including Indonesia. Based on the latest survey data, Indonesia's Maternal Mortality Rate (MMR) is 305/100,000 live births (SUPAS 2015) which is the third highest in ASEAN and the second highest in the South East region Asian Nation Regional Organization (WHO, 2013). The most common causes of maternal death in Indonesia are hypertension, pre-eclampsia, eclampsia, bleeding, and infection. (Litbangkes, 2016).

Globally, preeclampsia is still a problem, $10 \%$ of pregnant women worldwide experience preeclampsia, and it is the cause of 76,000 maternal deaths and 500,000 infant deaths each year. Based on research by the United States Agency for International Development (USAID) in 2016, $99 \%$ of maternal deaths are related to low and middle-income countries. In Indonesia, the prevalence of preeclampsia has increased every year from 2014-2016. In 2014 the prevalence of preeclampsia was $24.44 \%$ from 711 deaths per 100,000 live births, in 2015 it increased to $26.34 \%$ from 619 deaths per 100,000 live births, while in 2016 it also increased to $27.08 \%$ from 602 deaths per 100,000 live births.

According to secondary analysis data by the World Health Organization (WHO), it is reported that the global prevalence of eclampsia is $0.3 \%$. Data from each country show that the prevalence of this disease varies and is related to the socio-economic status of each region. In Indonesia, eclampsia are the causes of maternal death IJRP 2022, 92(1), 146-153; dol: $18.45199715 R$ RPercent while infant mortality was between 45 percent to 50 percent. 
Preeclampsia has quite an impact on renal function. Preeclampsia may be complicated by seizures: eclampsia. The greatest compromise occurs with the development of the HELLP syndrome (hemolysis, elevated liver enzymes and low platelet count). The HELLP syndrome, alongside preeclampsia, accounts for most maternal deaths associated with hypertension. The process is completely reversed by the delivery of the fetus and placenta, but intrauterine growth retardation and premature delivery pose major threats to the fetus.

Aside from preeclampsia, eclampsia, the incidence of anemia in Indonesia is still quite high. According to Riskesdas data (2018), the prevalence of anemia in Indonesia is $48.9 \%$ with the proportion of anemia in the age group 15-24 years and 25-34 years (Kemenkes RI, 2018). Globally, anemia affects 1.62 billion people (95\% CI: $1.50-1.74$ billion), which corresponds to $24.8 \%$ of the population Anemia is a serious global public health problem that particularly affects young children and pregnant women. WHO estimates that $42 \%$ of children less than 5 years of age and $40 \%$ of pregnant women worldwide are anaemic.

According to research conducted by Bilano, V L et al (2014) anemia, hypertension, and obesity are the highest risk factors for preeclampsia and eclampsia. Other diseases that can increase the risk of are diabetes mellitus, vascular and connective tissue disease, nephropathy, antiphospholipid antibody syndrome, older maternal age ( $\geq 30$ years), high BMI, history of chronic hypertension, gestational diabetes, cardiac or renal disease, pyelonephritis or urinary tract infection were significantly associated with higher preeclampsia/eclampsia risks. A current study by Sattar et al, has shown a significant relationship between anemia and hypertensive disorder in pregnancy. Other risk factors for chronic hypertension that can occur include advanced maternal age, obesity, type 2 diabetes mellitus, renal disease, and gestational diabetes mellitus in the index pregnancy.

The high prevalence of preeclampsia, eclampsia and anemia that occurred in pregnant women suggest this research to find out the correlation between anemia with preeclampsia and eclampsia in Dr. Soetomo Hospital Surabaya.

\section{Method}

The type of research is analytic observational with cross-sectional design. This study will analyze medical records of pregnant women with caesarean section delivery at Dr. Soetomo General Hospital, Surabaya. The variables of this research are classified as anemia as independent variable and preeclampsia/eclampsia as dependent variable. However, from the total samples obtained, about 8 patient samples were eliminated because of the incomplete medical records nor met the exclusion criteria. Thus, only 141 remaining samples meet the inclusion criteria of this research to be further analyzed using Chi-square in statistical tests. Inclusion criteria are pregnant woman aged 16-35 years old. Exclusion criteria are history of preeclampsia/eclampsia and gemelli.

\section{Result}

Table 1. Patients' Profile Based on Age

\begin{tabular}{lccccc}
\hline Age Category & Frequency $(\mathrm{n})$ & Percentage $(\%)$ & Minimum & Maximum & Mean \\
\hline$<21$ & 6 & $4.30 \%$ & & & \\
$21-25$ & 26 & $18.40 \%$ & 18 & 35 & 28 \\
$>25$ & 109 & $77 \%$ & & & \\
Total & 141 & $100 \%$ & & & \\
\hline
\end{tabular}


Table 1 describes the number of samples according to age. Categorized as under 21 with percentage of $4.30 \%, 21-25$ with percentage of $18.40 \%$ and above 25 with percentage of $77 \%$. Minimum number 18 , maximum number 35 and mean of 28 .

Table 2. Patients' Profile Based on Hemoglobin Level

\begin{tabular}{lccccc}
\hline $\mathrm{Hb}$ & Frequency $(\mathrm{n})$ & Percentage $(\%)$ & Minimum & Maximum & Mean \\
\hline$<11 \mathrm{~g} / \mathrm{dL}$ & 57 & $40.40 \%$ & & & \\
$\geq 11 \mathrm{~g} / \mathrm{dL}$ & 84 & $59.60 \%$ & $5 \mathrm{~g} / \mathrm{dL}$ & $15 \mathrm{~g} / \mathrm{dL}$ & 11.06 \\
Total & 141 & $100 \%$ & & \\
\hline
\end{tabular}

Table 2 describes the number of samples according to hemoglobin level. Categorized as under $11 \mathrm{~g} / \mathrm{dL}$ is 57 with percentage of $40.40 \%$ and more than equal to $11 \mathrm{~g} / \mathrm{dL}$ shows 87 with percentage of $59.6 \%$. The maximum number is $5 \mathrm{~g} / \mathrm{dL}$ with minimum number $15 \mathrm{~g} / \mathrm{dL}$ and mean of 11.06 .

Table 3. Patients' Profile Based on Gravida

\begin{tabular}{lcc}
\hline Gravida & Frequency (n) & Percentage (\%) \\
\hline Primigravida & 47 & $33.33 \%$ \\
Multigravida & 94 & $66.70 \%$ \\
Total & 141 & $100 \%$ \\
\hline
\end{tabular}

Table 3 describes the number of samples with primigravida is $47(33.33 \%)$ and multigravida of $94(66.70 \%)$.

Table 3. Patients' Profile Based on BMI

\begin{tabular}{lccccc}
\hline BMI Category & Frequency $(\mathrm{n})$ & Percentage $(\%)$ & Minimum & Maximum & Mean \\
\hline$<18.5$ & 1 & $0.70 \%$ & & & \\
$18.5-24.9$ & 21 & $14.90 \%$ & 18 & 35 & \\
$25.0-29.9$ & 57 & $40.4 \%$ & & \\
$\geq 30$ & 62 & $44.0 \%$ & & \\
Total & 141 & $100 \%$ & & \\
\hline
\end{tabular}

Table 3 presents BMI which categorized with underweight $<18.5(0.70 \%)$, normal $18-24.9(14.90 \%)$, overweight $25-29.9$ (44\%), and obese $\geq 30(37 \%)$. 
Table 4. Cross Tabulation Variable of Anemia and Preeclampsia/Eclampsia

\begin{tabular}{lcccc}
\hline \multirow{2}{*}{ Variable } & \multicolumn{2}{c}{ Anemia (+) } & Anemia (-) \\
\cline { 2 - 5 } & Frequency (n) & Percentage (\%) & Frequency (n) & Percentage (\%) \\
\hline Non-eclampsia & 50 & $69.40 \%$ & 33 & $47.80 \%$ \\
Preeclampsia & 5 & $6.90 \%$ & 10 & $14.50 \%$ \\
Severe Preeclampsia & 16 & $22.20 \%$ & 23 & $33.30 \%$ \\
Eclampsia & 1 & $1.40 \%$ & 3 & $4.30 \%$ \\
Total & 72 & $100.00 \%$ & 69 & $100.00 \%$ \\
\hline
\end{tabular}

Table 4 presents cross tabulation variable of anemia and preeclampsia/eclampsia shows patients with anemia in accordance to non-preeclampsia is $50(69.40 \%)$, preeclampsia $5(6.90 \%)$, severe preeclampsia 16 (22.20\%), and eclampsia 1 (1.40\%). Sample of patients without anemia shows 30 (47.80\%) non-preeclampsia 10 $(14.50 \%)$, preeclampsia, $23(33.30 \%)$, severe preeclampsia and $3(4.30 \%)$ eclampsia.

Table 5. Analysis Results of Correlation Between Anemia and Preeclampsia/Eclampsia

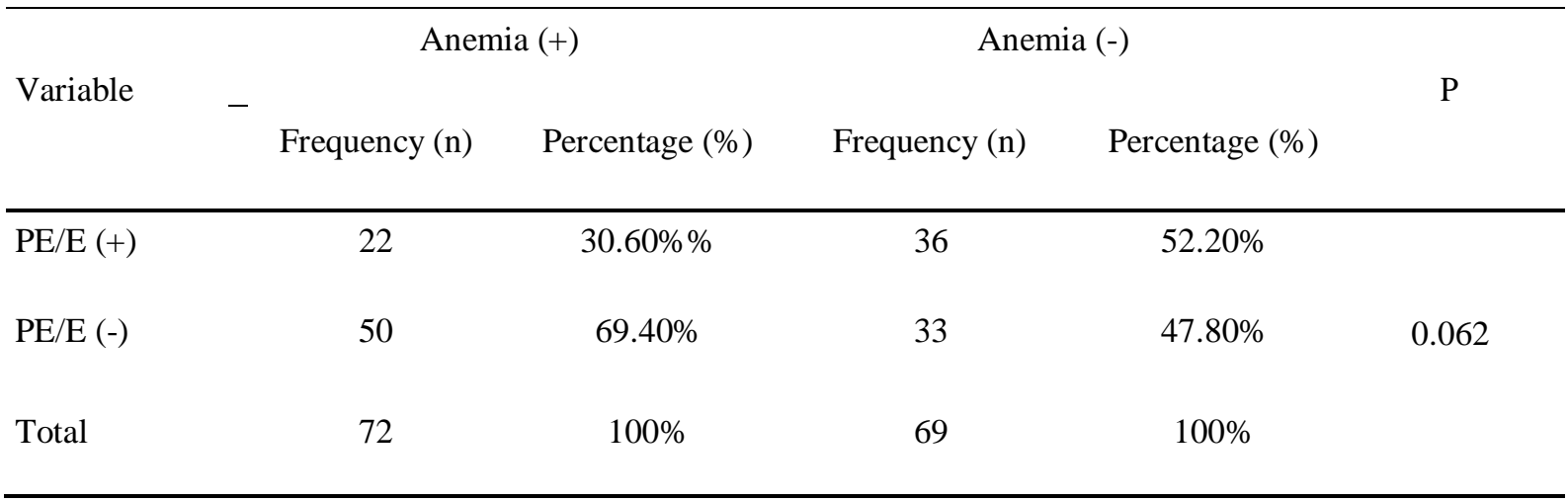

In table 5 presents the percentage of anemia patients with preeclampsia/eclampsia shows a number of 22 $(30.60 \%)$ and non-preeclampsia/eclampsia $50(69.40 \%)$. Non-anemia patients show higher percentage of preeclampsia/eclampsia with $36(52.20 \%)$ and number of non-preeclampsia/eclampsia $33(47.80 \%)$. Table 5 shows there is no correlation between anemia and preeclampsia/eclampsia because the value is $\mathrm{p}=0,062(\mathrm{p}>0,05)$.

\section{Discussion}

\subsection{Characteristic of pregnant woman}

The data on characteristics of pregnant women were analyzed in the form of age, hemoglobin to determine anemia, BMI to determine obesity, also primigravida and multigravida. In the profile of age characteristics, age less than 21 is $4.30 \%$. Between $21-25$ with a percentage of $18.40 \%$ and higher than 25 with percentage of $77 \%$. Maximum age taken by the sample was found at the age of 35 while the minimum was at the age of 18 .

According to characteristic patients based on hemoglobin, it was found the number of patients with hemoglobin level lower than $11 \mathrm{~g} / \mathrm{dL}$ is 57 (40.40\%) and more than equal to $11 \mathrm{~g} / \mathrm{dL}$ shows number of 87 (59.6\%). 
Based on the number of gravida divided into primigravida and multigravida. There were 47 pregnant women $(33.33 \%)$ with primigravida pregnancies and 94 pregnant women $(66.70 \%)$ with multigravida pregnancies. In BMI characteristic, it was found that the highest frequency is overweight (44\%), second highest is obese (37\%), normal BMI (14.90\%) and underweight $(0.70 \%)$

The total number of samples obtained were 141 pregnant women. The sample was analyzed for blood hemoglobin levels to diagnose anemia. The total number of anemia patients was found to be $40.40 \%$. Anemia without preeclampsia/eclampsia was $50(69.40 \%)$ and with preeclampsia/eclampsia showed a number of 22 (30.60\%).

Based on the characteristics of the degree of preeclampsia, it is divided into preeclampsia, severe preeclampsia, and eclampsia. In non-anemic patients, the percentage of preeclampsia was $14.50 \%$, severe preeclampsia $32.30 \%$ and $4.30 \%$ eclampsia. Meanwhile, patients with anemia indicate percentages of $5 \%$ preeclampsia, $16 \%$ severe preeclampsia, and 1\% eclampsia. The results stated that non-anemic patients had a higher percentage of developing preeclampsia, severe preeclampsia, and eclampsia compared to patients with a diagnosis of anemia.

\subsection{Analysis on Correlation Between Anemia and Preeclampsia/Eclampsia}

The analysis in this study was conducted to see the correlation between anemia with preeclampsia/eclampsia in pregnant women at Dr. Soetomo hospital. In the results of the chi-square statistical test, the value $(\mathrm{p}=0.062)$. Thus, it can be concluded that this study did not find a significant relationship between anemia and the incidence of preeclampsia/eclampsia in dr. Soetomo hospital.

During pregnancy, relatively anemia occurs because the blood of pregnant women undergoes hemodilution with an increase in volume of $30 \%$ to $40 \%$. Anemia in pregnancy as $\mathrm{Hb}<11 \mathrm{~g} \%$ in the first trimester and $<10.5 \mathrm{~g} \%$ in the second trimester, because during the second trimester there is a maximal physiological hemodilution process. Increased hemodilution of blood begins to appear in the second trimester of pregnancy. However, the increase in blood cells is not balanced with the increase in blood volume, resulting in hemodilution accompanied by physiological anemia. In pregnancy, oxygen demand is higher, which triggers an increase in erythropoietin production. As a result, the volume of plasma increases and red blood cells (erythrocytes) increase. However, the increase in plasma volume occurs in a greater proportion when compared to the increase in erythrocytes, resulting in a decrease in hemoglobin concentration $(\mathrm{Hb})$ due to hemodilution. (Manuaba.I.B.G, 2010).

In this study, the total patient sample was in the third trimester. So if physiologically, the hemoglobin level obtained in the third trimester was not as low as in the second trimester due to the hemodilution process.

In a cohort study conducted by Malihe Nasiri (2015), showed that low hemoglobin levels or anemia were not associated with preeclampsia. Preeclampsia occurs in pregnant women who have high hemoglobin levels. In pregnant women who have high and oxidized hemoglobin levels, there will be the formation of deposits on the endothelium, this can also be found in the placenta of pregnant women who have preeclampsia.

This research is contrary to the research conducted by Maulina Intan (2013) the results obtained from 44 patients with a diagnosis of preeclampsia and eclampsia, there were 34 people (77\%) who had anemia. In the study of Ali et al (2011) women with severe anemia had a 3.6 times higher risk of preeclampsia than women without anemia. Rohilla's (2010) study observed that 17 (17.7\%) of 97 women with severe anemia had gestational hypertension or preeclampsia and $2(2.1 \%)$ had eclampsia. Vulnerability of women with anemia for preeclampsia due to deficiency of micronutrients and antioxidants. (Ali, AA et al, 2011). Micronutrients include calcium, phosphorus, sodium, potassium, iron, zinc, copper, magnesium, vitamin B complex, vitamin C, vitamin A, vitamin D, vitamin E, vitamin K (Barasi. M.E, 2007). Deficiency of calcium and protein substances in the diet of pregnant women can lead to the risk of preeclampsia (Saifuddin, 2011).

Another possibility that occurs is that the distribution of anemia data with preeclampsia/eclampsia is less than in non-anemic patients with preeclampsia/eclampsia. It is possible that there are other risk factors other than anemia that influence the incidence of preeclampsia/eclampsia. 


\section{Conclusion}

The conclusion of this research is there is no correlation between anemia with preeclampsia and eclampsia. Thus, anemia is not a risk factor for the occurrence of preeclampsia and eclampsia in pregnant women at Dr. Soetomo Hospital, Surabaya. The possibility of the incidence of preeclampsia/eclampsia might influenced by other risk factor such as obesity, gravida, and maternal age.

\section{Acknowledgements}

Praise and gratitude to Almighty Allah SWT for His blessing and grace, thus, we were able to finish this research entitled No Correlation Between Anemia and Preeclampsia/Eclampsia. We would also send our gratitude to obstetric and gynecological patients as our samples. Thereafter, we also acknowledge Dr. Aditiawarman, dr., SpOG(K) and Dr. Ni Wajan Tirthaningsih, dr. MS., PA(K) for the guidance to finish this paper. Finally, our deep and sincere gratitude to our family for the continuous and unparalleled love, help and support.

\section{References}

Ali, A., Rayis, D., Abdallah, T., Elbashir, M. and Adam, I., 2011. Severe anaemia is associated with a higher risk for preeclampsia and poor perinatal outcomes in Kassala hospital, eastern Sudan. BMC Research Notes, 4(1).

Barasi, ME (2007). At A Glance IlmuGizi.Jakarta.Erlangga. p80

Bilano, V., Ota, E., Ganchimeg, T., Mori, R. and Souza, J., 2014. Risk Factors of Pre-Eclampsia/Eclampsia and Its Adverse Outcomes in Low- and Middle-Income Countries: A WHO Secondary Analysis. PLoS ONE, 9(3), p91198.

CDC criteria for anaemia in children and childbearing-aged women. Morbidity and Mortality Weekly Report, 1989, 38(22):400-404.

Cunningham FG et al. (2014). Hypertensive Disorder in Pregnancy. Dalam C. F. al, William Obstetrics 24th Ed. New York: McGraw-Hill Companies Inc.

Departemen Kesehatan RI. 2012. Survei Demografi Kesehatan Indonesia dan Angka Kematian Ibu. Dari http://www.depkes.go.id [Accessed 20 August 2021].

Litbangkes, 2016. [online]Ejournal.litbang.kemkes.go.id. Available at: <http://ejournal.litbang.kemkes.go.id/index.php/kespro/article/download/5438/4474> [Accessed 2 January 2022].

Manuaba. 2010. Ilmu kebidanan, Penyakit Kandungan, dan KB. Jakarta: EGC

M. Rohilla, A. Raveendran, L. K. Dhaliwal \& S. Chopra (2010) Severe anaemia in pregnancy: A tertiary hospital experience from northern India, Journal of Obstetrics and Gynaecology, 30:7, 694-696.

Nasiri, M., Faghihzadeh, S., Alavi Majd, H., Zayeri, F., Kariman, N. and Safavi Ardebili, N., 2015. Longitudinal Discriminant Analysis of Hemoglobin Level for Predicting Preeclampsia. Iranian Red Crescent Medical Journal, 17(3), pp.1-4.

Riskesdas, 2018. [online] Pusdatin.kemkes.go.id. Available at: <https://pusdatin.kemkes.go.id/resources/download/general/Hasil\%20Riskesdas\%202013.pdf> [Accessed 2 January 2022].

Saifuddin, A., n.d. Buku panduan praktis pelayanan kesehatan maternal dan neonatal.

SUPAS, 2015. Pusat Data dan Informasi - Kementerian Kesehatan Republik Indonesia. [online] Pusdatin.kemkes.go.id. Available at: <https://pusdatin.kemkes.go.id/article/view/17120500001/pelayanan-darah-di-indonesia-2017.html> [Accessed 2 January 2022]. 
Usaid.gov.

2021

[online]

Available

at:

<https://www.usaid.gov/sites/default/files/USAID_2016_MCS_AOTC_Brochure_V15_single_SMALL_

508v2.pdf> [Accessed 4 January 2022].

IWHO 2011, Haemoglobin concentrations for the diagnosis of anaemia and assessment of severity. Vitamin and Mineral Nutrition Information System. Geneva, World Health Organization http://www.who.int/vmnis/indicators/haemoglobin.pdf, accessed 11 November 2021).

\section{Appendix}

A. Raw data

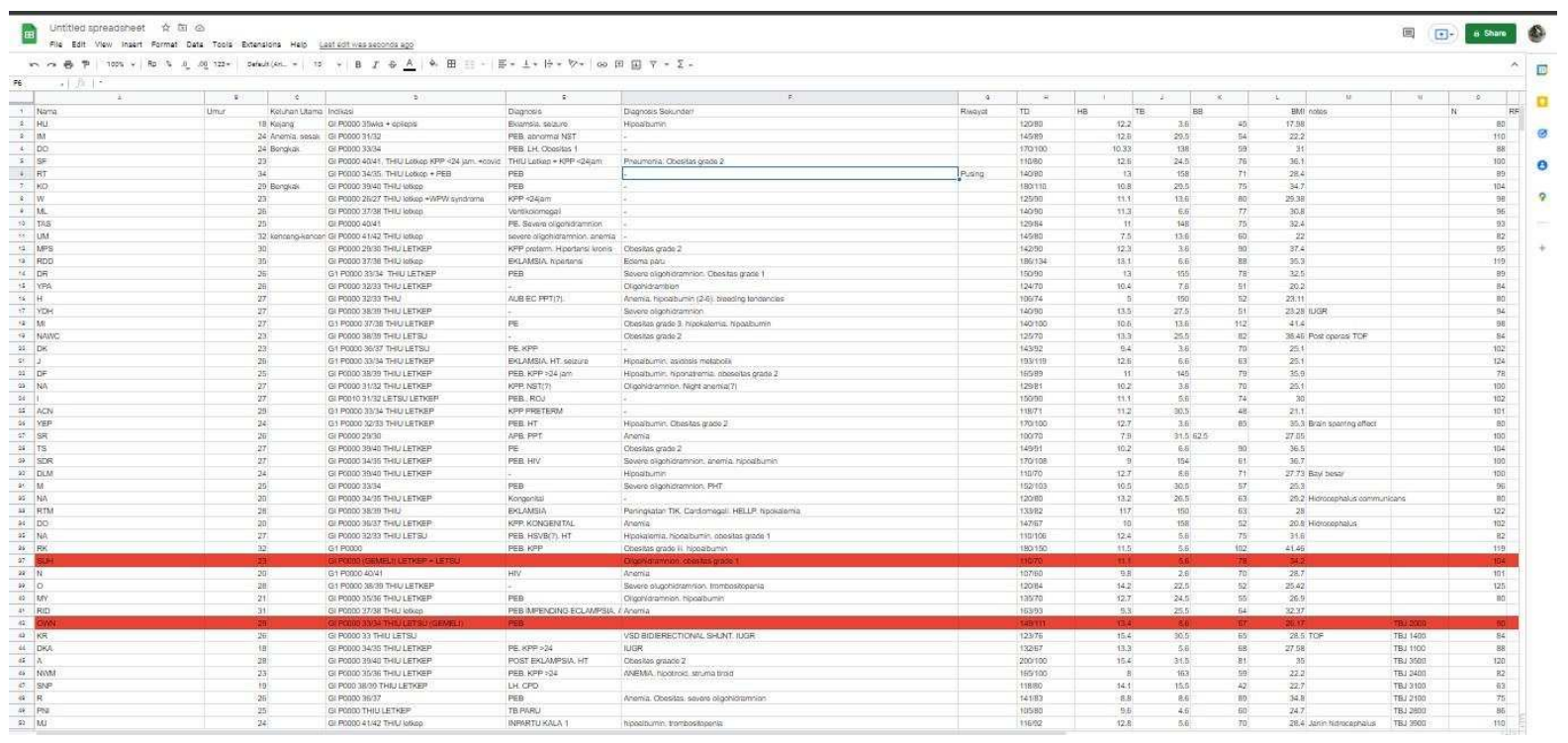

B. Analysis Result

B.1 Obsevational Analytic

\begin{tabular}{|l|l|r|}
\hline \multicolumn{3}{|c|}{ Statistics } \\
\hline gee \\
\hline & Vail & 141 \\
\hline & Wrssing & 0 \\
\hline
\end{tabular}

\begin{tabular}{|c|c|c|c|c|c|}
\hline \multicolumn{6}{|c|}{ Age } \\
\hline & & & & & Cumnulabve \\
\hline & & Frequetency & Purvent & Valid Purcent & Parcaenit \\
\hline Balit & 100 & 6 & 4.3 & 4.3 & 43 \\
\hline & 200 & 26 & 18.4 & 18.4 & 22.7 \\
\hline & 300 & 709 & 77.3 & 77.3 & 500.6 \\
\hline & Tctal & 541 & 1000 & 100.0 & \\
\hline
\end{tabular}

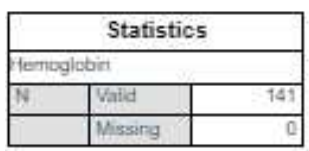

\begin{tabular}{|c|c|c|c|c|c|}
\hline \multicolumn{6}{|c|}{ Hemoglobin } \\
\hline & & Frequency & Percant & Valid Percent & $\begin{array}{l}\text { Cumblative } \\
\text { Porcents }\end{array}$ \\
\hline Valld & 10 & 57 & 40.4 & 40.4 & 40.4 \\
\hline & $11-20$ & 84 & 59.6 & 59.6 & 900.0 \\
\hline & Toinil & 141 & 100.0 & 1000 & \\
\hline
\end{tabular}

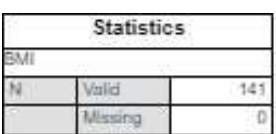

\begin{tabular}{|c|c|c|c|c|c|}
\hline \multicolumn{6}{|c|}{ BMI } \\
\hline & & Frequency & Percent & Vuilid Percent & $\begin{array}{l}\text { Cumulative } \\
\text { Purcent }\end{array}$ \\
\hline \multirow[t]{5}{*}{ Vuld } & 100 & $T$ & 7 & 7 & 7 \\
\hline & 2.00 & 27 & 14.9 & 74.9 & 15.6 \\
\hline & 3.00 & 51 & 40.4 & 40,4 & 56.0 \\
\hline & 6.00 & $t=$ & 44.0 & 44.0 & 100.0 \\
\hline & Total & 141 & 100.0 & 100.0 & \\
\hline \multicolumn{2}{|l|}{ Togal } & 149 & 1000 & & \\
\hline
\end{tabular}
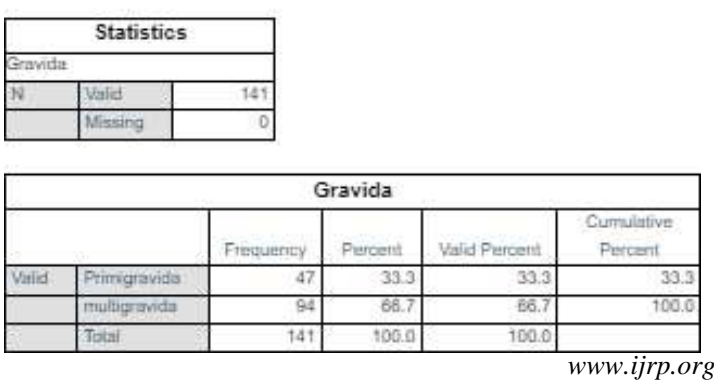
B.2 Analytical Analysis

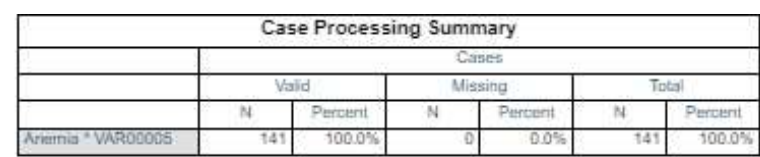

\begin{tabular}{|c|c|c|c|c|c|c|c|}
\hline \multicolumn{8}{|c|}{ Anemia * VAR00005 Crosstabulation } \\
\hline & & & & VARDO0005 & & & \\
\hline & & & $\begin{array}{c}\text { Nan Preedin } \\
\text { mpesia }\end{array}$ & $\begin{array}{c}\text { Preecturyseni } \\
\text { a }\end{array}$ & \begin{tabular}{|c|} 
Severe \\
Preediampsi \\
a
\end{tabular} & & \\
\hline Anemente & $\begin{array}{l}\text { Som Phen } \\
2\end{array}$ & Conuth & 33 & & 23 & & \\
\hline & & 5o willin Aneming & $47.8 \%$ & 1455 & $30.3 \%$ & & \\
\hline & & \begin{tabular}{|l} 
iventhin \\
VAR000005
\end{tabular} & $29,6 \%$ & 66.75 & $59.0 \%$ & & \\
\hline & & Sis al Tolal & $23.4 \%$ & 7.15 & $16.3 \%$ & & \\
\hline & Anemia & Covith & 50 & 5 & 16 & & \\
\hline & & Th- wilfin Anemia & $69.4 \%$ & 695 & $222^{2 \pi}$ & & \\
\hline & & \begin{tabular}{|l} 
S wilhing \\
VAR00005
\end{tabular} & $60.2 \%$ & 3335 & 41.05 & & \\
\hline & & Txal Tatal & $35,5 \%$ & 355 & $\pi 1,3 \mathrm{se}$ & & \\
\hline Total & & Count & 83 & 15 & 39 & & \\
\hline & & Siwithin Aromias & $58.9 \%$ & $10.6 \%$ & 27.75 & & \\
\hline & & 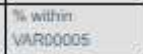 & $100.0 \%$ & $100.0 \%$ & $100.0 \%$ & & \\
\hline & & Txal Tolal & 56.976 & $10.6 \%$ & 27.73 & & \\
\hline
\end{tabular}

\begin{tabular}{|c|c|c|c|}
\hline \multicolumn{4}{|c|}{ Chi-Square Tests } \\
\hline & Value & d & 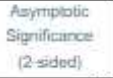 \\
\hline Posaryon Con/Spulre & $7.344^{\circ}$ & & .062 \\
\hline Likeihood Ranó & 7.452 & & .059 \\
\hline Linear by Linewis Asactiason & 5.720 & & .017 \\
\hline Tof Vald Canes & 141 & & \\
\hline
\end{tabular}

